\title{
ДІАГНОСТИКА УПРАВЛІННЯ РОЗВИТКОМ ФІНАНСОВОЇ ДІЯЛЬНОСТІ АГРАРНИХ ПІДПРИЄМСТВ ОДЕСЬКОЇ ОБЛАСТІ
}

\author{
THE FINANCIAL ACTIVITIES DEVELOPMENT \\ MANAGEMENT DIAGNOSIS FOR AGRICULTURAL \\ ENTERPRISES OF ODESSA REGION
}

\author{
Барбінягра Олександр Миколайович \\ аспірант, \\ Одеський державний аграрний університет \\ ORCID: https://orcid.org/0000-0002-8496-4223
}

Barbinyagra Alexander
Odessa State Agrarian University

У статті проведено діагностику управління розвитком фінансової діяльності аграрних підприємств Одеської області. Діагностика здійснена на основі розрахунку показників фрінансового стану, співставлення фрактичних показників з їх нормативними значеннями. Визначено відхилення показників, для яких не встановлене нормативне значення, від середнього їх рівня в Україні. На основі кореляційного аналізу сформовано схему взаємозв'язків між показниками фрінансового стану аграрних підприємств. Встановлено, що найбільший вплив на показники фрінансового стану здійснюють період погашення дебіторської заборгованості та коефіцієнт маневреності власного капіталу. Обчислено коефіцієнти ефеективності управління розвитком фрінансової діяльності аграрних підприємств. Проведено регресійний аналіз ефективності управління розвитком фінансової діяльності аграрних підприємств.

Ключові слова: фрінансова діяльність, управління розвитком фрінансової діяльності, аграрні підприємства, оцінка ефективності, фрактори есрективного управління.

В статье проведена диагностика управления развитием фринансовой деятельности аграрных предприятий Одесской области. Диагностика осуществлена на основе расчета показателей фринансового состояния и сопоставления с нормативными значениями. Определены отклонения показателей, для которых не установлено нормативное значение, от среднего их уровня в Украине. На основе корреляционного анализа ссормирована схема взаимосвязей между показателями фринансового состояния аграрных предприятий. Установлено, что наибольшее влияние на показатели фринансового состояния осуществляют период погашения дебиторской задолженности и коэффициент маневренности собственного капитала. Вычислено коэффициенты эфрфрективности управления развитием фринансовой деятельности аграрных предприятий. Проведен регрессионный анализ эффрективности управления развитием финансовой деятельности аграрных предприятий.

Ключевые слова: фринансовая деятельность, управление развитием финансовой деятельности, аграрные предприятия, оценка эффрективности, фракторы эффективного управления.

The article diagnoses the financial activities development management of agricultural enterprises of Odessa region on the basis of efficiency assessment and identification of internal factors of its increase. The empirical basis of the study is the data for 2015-2020 reports on the financial condition and reports on the financial results of fifteen agricultural enterprises of Odessa region. 38 financial indicators are calculated for these enterprises. The analysis of activity of the agricultural enterprises of the Odessa region on the basis of comparison of 20 indicators with existing standard values is carried out. Deviations of 18 indicators without normative value from the average level in Ukraine are determined. On the basis of the correlation analysis the scheme of interrelations between financial indicators of the agrarian enterprises of the Odessa region is formed. It is established that the greatest influence on financial indicators is exerted by the period of repayment of receivables and the coefficient of maneuverability of equity. Coefficients of efficiency for financial activity development management of the Odessa region agrarian enterprises are calculated and researched enterprises are divided into three groups on dynamics of formation of an indicator during 2015-2020: tendency to growth, insignificant decreasing tendency, decreasing tendency. A regression analysis of the financial activity development management efficiency of the Odessa region agrarian enterprises is implemented 
for the following factors: the number of employees, level of specialization, number of funding sources, growth rate of book value of assets, crop yield. It is established that these factors have a direct proportional impact on the financial activity development management efficiency of agricultural enterprises. The study found that despite the adequacy of working capital to ensure the production and marketing process in conditions of limited borrowing, sufficient equity to finance assets, the adequacy of current assets for timely settlement of liabilities, timely repayment of receivables by customers, as well as availability of financial autonomy and stability, agricultural enterprises of Odessa region inefficiently manage stocks and accounts payable, as well as have an insufficient level of net profit margin and operating profit margin.

Keywords: financial activity, management of financial activity development, agricultural enterprises, efficiency assessment, factors of effective management.

Постановка проблеми. Результативність будь-якого управлінського процесу потребує аналізу, контролю, а отже діагностики й оцінювання. Управління розвитком срінансової діяльності спрямоване, в першу чергу, на забезпечення постійного покращення орінансового стану підприємства та формування фрінансової стійкості. Особливо гостро постає необхідність діагностики даного процесу в аграрній сорері, яка являється пріоритетним напрямом економіки України, зважаючи на те, що аграрний сектор продукує близько $15 \%$ ВВП та тут працевлаштоване близько $16 \%$ зайнятого населення країни. Але значна частка аграрних підприємств, особливо тих, що є малими та середніми суб'єктами господарювання, перебуває в нестійкому фрінансовому стані та потребує організації більш едрективного управління фрінансовою діяльністю, а це, в свою чергу, вимагає здійснення діагностики управління її розвитком.

Аналіз останніх досліджень и публікацій. Дослідженню фрінансових аспектів управління діяльністю підприємств та діагностики орінансового стану присвячено чимало досліджень зарубіжних та вітчизняних науковців. Сучіу Г. та Берсан П.-Н., досліджуючи фрінансову діагностику активів компаній, відзначають її перевагу в управлінні фрінансами, яка полягає в тому, що вона дає можливість складати стратегії, пов'язані з майбутньою діяльністю, та роблять висновок, що відповідний діагноз можна поставити лише після аналізу якомога більшої кількості фрінансових показників і коли існують стандарти (нормативи) для діагностики і оцінки [1].

Сучіу Г. також досліджує, за яких умов забезпечується фрінансова рівновага та робить висновок, що діагностика фрінансової рівноваги враховує 2 складові: джерела фрінансування (власний капітал, позичений, тимчасово залучений), а ефективна фрінансова рівновага, на його думку, повинна відповідати основним вимогам: наявність постійних джерел, представлених власним капіталом та позиками понад 1 рік.
Досліджуючи проблеми діагностики фрінансового стану і стійкості фрункціонування підприємства, Копчак Ю.С. звертає увагу на те, що, зважаючи на велику кількість шляхів поліпшення фрінансового стану підприємства, існує низка перешкод, що заважає їх упровадженню в діяльність суб'єктів господарської діяльності, серед яких автор виділяє об'єктивні, зокрема стан фрінансової кон'юнктури на ринках даного підприємства [3, с. 23].

Лук'янова В.В. і Лабунець О.О. вказують на необхідність «докладно проаналізувати загрози від негативних важелів, що мають вплив на фрінансовий стан, можуть спричинити збитки підприємству, а також усебічно оцінити результати фрінансово-господарської діяльності підприємства в розрізі діагностики його фрінансового стану, щоб забезпечити економічну безпеку підприємства» [4, с. 68].

На думку Мищишин О.Л. та Федорович I.C., для діагностики фрінансового забезпечення підприємства доцільно використовувати такі критерії оцінки стану фрінансових ресурсів підприємства, як: структура срінансового забезпечення діяльності підприємства; відповідність структури фрінансування активам підприємства; склад резервів підприємства [5, с. 655]. При цьому автори підкреслюють, що «...3 метою есрективного управління розвитком підприємства доцільно використовувати комплексний підхід до формування системи показників діагностики стану забезпеченості фрінансовими ресурсами, що $є$ дуже важливим в умовах конкурентної боротьби» [5, с. 655].

Відносно удосконалення механізму фрінансової діагностики у публікації Горбунової А.В. автор звертає увагу на те, що діагностика фрінансового стану має бути спрямована на те, щоб ще на ранніх стадіях внаслідок систематичної перевірки за цілеспрямовано введеними фрункціональними складовими можна було б ідентифрікувати і якомога швидше ліквідувати негативний вплив різних видів деструктивних фракторів [6, с. 15-16]. 
Значна увага науковцями звертається на показники, що застосовуються в діагностиці фрінансового стану. Так, Підхомний О.М., відзначає, що основними показниками, які визначають фрінансовий стан підприємства, $€$ : показники ліквідності та платоспроможності; показники оцінки фрінансової стійкості; показники ділової активності; показники аналізу рентабельності та інші [7, с. 234].

Маринич І.А., Дзіковський І.І. обґрунтовують сучасні підходи до діагностики фрінансового потенціалу підприємства [8]. Левченко Н.М. висвітлює розроблений принциповий алгоритм управління фрінансовим потенціалом підприємств 3 урахуванням тенденцій фрункціонування підприємства в мінливому зовнішньому середовищі [9].

Марченко В.В. зазначає, що як величина рівня фрінансового забезпечення розвитку продуктивних сил, так і запас фрінансової міцності підприємства, $€$ важливими локальними критеріями під час обґрунтування тактичних і стратегічних управлінських рішень щодо забезпечення стабільного інноваційного розвитку підприємства [10]. Варава Л.М., Асранасьєв Є.В., Арутюнян А.Р. здійснили комплексну інтегровану діагностику рівня есрективності корпоративного управління на основі фрінансово-економічних показників підприємства [11].

Привертають увагу дослідження, якими пропонуються нові методичні рішення у фінансовій діагностиці. Так, Кривов'язюк І.В. та Кость Я.О. висвітлюють питання математико-статистичного моделювання у фрінансовій діагностиці підприємств [12].

Діагностиці фрінансового управління в системі фрінансового менеджменту аграрних підприємств та окремим її аспектам також приділяється значна увага науковцями. Найда А.В. та Тоткало І.А. виявили низку фракторів, що стримують зростання прибутковості та рентабельності аграрних підприємств, серед яких недосконалість податкової політики в аграрному секторі, яка не є лояльною та не виконує стимулюючої срункції, недоступність кредитних ресурсів [13].

Ряд наукових публікацій містить обґрунтування методичних підходів до аналізу та діагностики окремих аспектів фрінансового управління. Бахчиванжи Л.А. та Пучко Н.С. здійснюють аналіз та діагностику дебіторської заборгованості в акціонерних товариствах 3 урахуванням особливостей акціонерної фрорми підприємств та запропонували економетричні модель для прогнозування дебіторської забор- гованості та виявлення негативних фракторів ії фрормування. Авторами також запропоновані показники, що можуть бути використані в аналізі і діагностиці та аудиті дебіторської заборгованості [14]. Висвітлені та обґрунтовані у наукових публікаціях й такі аспекти аналізу та діагностики фрінансів аграрних підприємств, як управління зростанням фрінансових результатів та обсягів реалізації продукції [15], методика аналізу та планування прибутку [16], стратегія відтворення основних засобів аграрних підприємств [17], діагностика обліково-аналітичного забезпечення управління біологічними активами [18]. Окремі складові діагностики фрінансового забезпечення та аналізу фрінансового стану аграрних підприємств Одеської області знайшли відображення в публікаціях Конопльової О.І. [19], Морозюк Н.С., Стоянової-Коваль С.С., Губко В.І. [20], Лівінського А.І. [21].

Виділення невирішених раніше частин загальної проблеми. Аналіз публікацій з питань діагностики фрінансового стану аграрних підприємств вказує на відсутність комплексних досліджень та обґрунтування методичних підходів до діагностики управління розвитком фрінансової діяльності малих суб'єктів господарювання аграрного сектора різних організаційно-правових форм та форм власності. Вимагають обґрунтування методи, система показників, взаємозв'язок фракторів, що визначають ефективність управління срінансовим розвитком 3 урахуванням особливостей діяльності аграрних підприємств та багатоукладності аграрного сектора економіки України.

Формулювання цілей статті (постановка завдання). Метою статті $\epsilon$ діагностика управління розвитком фрінансової діяльності аграрних підприємств Одеської області на основі оцінки есрективності та виявлення внутрішніх фракторів її підвищення.

Виклад основного матеріалу дослідження. Аграрний сектор Одеської області характеризується багатоукладністю економіки, відмінною особливістю якої $€$ наявність підприємств різних організаційно-правових форм, розмірів господарювання та форм власності, які накладають свій відбиток на формування фрінансового потенціалу підприємств, їх фрінансовий стан та потенційні можливості конкурентоспроможного фрункціонування. Необхідність забезпечення ефективного управління розвитком фрінансової діяльності вимагає удосконалення наукового та методичного забезпечення з урахуванням 
відзначених особливостей підприємств та умов невизначеності ринкової економіки.

Діагностика всіх аспектів управління, зокрема й підсистеми фрінансового менеджменту вимагає належного інфрормаційного та аналітичного забезпечення. Емпіричною базою даного дослідження послужили показники фрінансової звітності, зокрема «Звіту про фрінансовий стан» та «Звіту про фрінансові результати» сукупності п'ятнадцяти підприємств Одеської області, у складіякихпредставлені8підприємствдержавної форми власності та 7 акціонерних підприємств: ДП ДГ «Комунар», ДП ДГ «Мирнопільське», ДП ДГ «Реконструкція», ДП ДГ «Жеребківське», ДП ДГ «Зелені Кошари», ДП ДГ «Покровське», ДП ДГ «Дачна», ПрАТ «Перемога», ПрАТ «Долинка», ПрАТ «Дружба», ПрАТ «Старосілля», ПрАТ «Ізмаїл-Наваско», ДП ДГ «Южний», ПАТ «Сонячне» та ПАТ «Мирний» [22].
Всізазначені підприємства є типовими за розмірами господарювання, чисельністю штатних працівників протягом 2015-2020 рр. (у середньому 52 особи), а основним видом їх економічної діяльності за КВЕД України $є 01.11$ «Вирощування зернових культур (крім рису), бобових культур і насіння олійних культур».

На основі даних фрінансової звітності було розраховано 38 показників фрінансового стану за період 2015-2020 років для п'ятнадцяти підприємств, тобто для кожного коефріцієнта отримано 90 досліджень. Описова статистика наведена у таблиці 1 та таблиці 2.

У результаті діагностики фрінансового стану аграрних підприємств Одеської області за період 2015-2020 років було виявлено, що більшість $з$ підприємств характеризується нормативним або наближеним до нього значенням за наступними показниками: коефі-

Описова статистика для показників з нормативним значенням, 2015-2020 рр.

Таблиця 1

\begin{tabular}{|l|c|c|c|c|c|}
\hline \multicolumn{1}{|c|}{ Показники } & $\begin{array}{c}\text { Середнє } \\
\text { значення }\end{array}$ & Медіана & Мінімум & Максимум & $\begin{array}{c}\text { Стандартне } \\
\text { відхилення }\end{array}$ \\
\hline Коесріцієнт абсолютної ліквідності & 1,5 & 0,0 & 0,0 & 25,2 & 4,4 \\
\hline $\begin{array}{l}\text { Коесріцієнт забезпечення власними } \\
\text { оборотними засобами запасів }\end{array}$ & 7,3 & 1,0 & $-69,2$ & 232,0 & 35,5 \\
\hline $\begin{array}{l}\text { Коесріцієнт забезпеченості } \\
\text { власними оборотними засобами }\end{array}$ & 0,3 & 0,7 & $-6,0$ & 9,2 & 1,7 \\
\hline $\begin{array}{l}\text { Коесріцієнт концентрації позикового } \\
\text { капіталу }\end{array}$ & 0,2 & 0,1 & 0,0 & 0,9 & 0,2 \\
\hline $\begin{array}{l}\text { Коесріцієнт маневреності власного } \\
\text { капіталу }\end{array}$ & 0,3 & 0,4 & $-2,4$ & 1,0 & 0,6 \\
\hline Маржа операційного прибутку & $-6,8$ & 12,6 & -563 & 50,1 & 84,8 \\
\hline Маржа чистого прибутку & $-14,1$ & 1,3 & -566 & 50,1 & 86,0 \\
\hline $\begin{array}{l}\text { Коесріцієнт оборотності дебіторської } \\
\text { заборгованості }\end{array}$ & 27,1 & 17,1 & 0,1 & 201,9 & 36,0 \\
\hline Коесріцієнт оборотності запасів & 5,4 & 1,9 & 0,2 & 244,0 & 25,6 \\
\hline $\begin{array}{l}\text { Коесріцієнт оборотності } \\
\text { кредиторської заборгованості }\end{array}$ & 119,3 & 11,6 & 0,0 & 4748,7 & 546,5 \\
\hline Період одного обороту запасів & 278 & 186 & 1 & 1715 & 284 \\
\hline $\begin{array}{l}\text { Період погашення дебіторської } \\
\text { заборгованості }\end{array}$ & 204 & 21 & 2 & 4058 & 614 \\
\hline $\begin{array}{l}\text { Період погашення кредиторської } \\
\text { заборгованості }\end{array}$ & 133 & 23 & 0 & 1204 & 229 \\
\hline Коесріцієнт поточної ліквідності & 16,3 & 6,3 & 0,0 & 338,8 & 40,8 \\
\hline Коесріцієнт реінвестування & 60,1 & 100,0 & -546 & 640,0 & 104,7 \\
\hline $\begin{array}{l}\text { Співвідношення короткострокової } \\
\text { дебіторської та кредиторської } \\
\text { заборгованості }\end{array}$ & 11,0 & 0,6 & 0,0 & 412,1 & 46,1 \\
\hline Коесріцієнт швидкої ліквідності & 4,9 & 1,5 & $-18,3$ & 54,8 & 9,4 \\
\hline Коесріцієнт орінансової автономії & 0,8 & 0,9 & 0,1 & 1,0 & 0,2 \\
\hline Коесріцієнт фрінансової стабільності & 24,3 & 6,7 & 0,0 & 556,9 & 68,1 \\
\hline Коесріцієнт орінансової стійкості & 0,8 & 0,9 & 0,1 & 1,0 & 0,2 \\
\hline
\end{tabular}


цієнт забезпечення власними оборотними засобами запасів, коефіцієнт забезпеченості власними оборотними засобами, коефіцієнт маневреності власного капіталу, період погашення дебіторської заборгованості, коефріцієнт швидкої ліквідності, коефріцієнт фрінансової автономії, коефріцієнт фрінансової стабільності, коефріцієнт фрінансової стійкості. Попри це, в переважній кількості досліджуваних підприємств відзначалася тенденція до збільшення відхилення від норми маржі операційного прибутку, маржі чистого прибутку, коефріцієнта оборотності запасів, коесріцієнта оборотності кредиторської заборгованості, періоду погашення кредиторської заборгованості та співвідношення короткострокової кредиторської до дебіторської заборгованості.

Компаративний аналіз показників фрінансового стану дозволив встановити, що у досліджуваних аграрних підприємств Одеської області, на відміну від показників по Україні, значно вищий рівень мають коефіцієнт оборотності оборотних активів, період виробничого циклу, період окупності активів, період окуп- ності власного капіталу, коесріцієнт фрондовіддачі та частка основних засобів в активах, а коесріцієнт маневреності власних оборотних коштів, період фрінансового циклу, коефіцієнт рентабельності активів, коефріцієнт рентабельності власного капіталу та коефіцієнт стійкості економічного зростання набувають негативного значення. Зазначене вказує на гірший орінансовий стан досліджуваних підприємств у порівнянні із загальним галузевим рівнем.

Для виявлення точок впливу на фрінансовий стан аграрних підприємств України проведено кореляційний аналіз 38-ми показників фрінансового стану протягом 2015-2020 рр. (рис. 1).

Виявлені взаємозв'язки дозволяють розподілити їх на дві підсистеми, які між собою мають посередню кореляцію, а всередині суттєву. Отже, при удосконаленні аграрними підприємствами політики управління дебіторською заборгованістю для зменшення періоду ії погашення відбудуться такі позитивні зміни: збільшення маржі чистого та операційного прибутку, скорочення операційного та фрінансового циклів, зменшення одного обороту обо-

Таблиця 2

Описова статистика для показників без нормативного значення, 2015-2020 рр.

\begin{tabular}{|l|c|c|c|c|c|}
\hline \multicolumn{1}{|c|}{ Показники } & $\begin{array}{c}\text { Середнє } \\
\text { значення }\end{array}$ & Медіана & Мінімум & Максимум & $\begin{array}{c}\text { Стандартне } \\
\text { відхилення }\end{array}$ \\
\hline $\begin{array}{l}\text { Коефіцієнт маневреності власних } \\
\text { оборотних коштів }\end{array}$ & 0,0 & 0,0 & $-0,9$ & 0,6 & 0,2 \\
\hline Коефріцієнт мобільності активів & 3,3 & 1,1 & 0,0 & 37,7 & 7,1 \\
\hline Коефіцієнт оборотності активів & 0,7 & 0,6 & 0,0 & 2,0 & 0,4 \\
\hline $\begin{array}{l}\text { Коефріцієнт оборотності власного } \\
\text { капіталу }\end{array}$ & 1,1 & 0,9 & 0,0 & 4,1 & 0,9 \\
\hline $\begin{array}{l}\text { Коефіцієнт оборотності оборотних } \\
\text { активів }\end{array}$ & 1,7 & 1,5 & 0,0 & 10,4 & 1,5 \\
\hline Період виробничого циклу & 278 & 186 & 1 & 1715 & 284 \\
\hline $\begin{array}{l}\text { Період одного обороту оборотних } \\
\text { активів }\end{array}$ & 836 & 235 & 35 & 12317 & 2034 \\
\hline Період окупності активів & 252 & 19 & -58 & 14831 & 1565 \\
\hline Період окупності власного капіталу & 109 & 14 & -55 & 4620 & 492 \\
\hline Період операційного циклу & 482 & 258 & 31 & 4228 & 694 \\
\hline Період орінансового циклу & 349 & 195 & -500 & 4181 & 645 \\
\hline Коефріцієнт покриття запасів & 10,7 & 1,4 & 0,0 & 260,3 & 38,7 \\
\hline Коефіцієнт рентабельності активів & 4,1 & 1,3 & $-39,4$ & 53,0 & 14,3 \\
\hline $\begin{array}{l}\text { Коефріцієнт рентабельності власного } \\
\text { капіталу }\end{array}$ & 5,0 & 1,7 & -132 & 59,1 & 23,5 \\
\hline $\begin{array}{l}\text { Коефріцієнт стійкості економічного } \\
\text { зростання }\end{array}$ & $-1,1$ & 0,0 & -388 & 58,6 & 46,5 \\
\hline Коефіцієнт фрондовіддачі & 6,5 & 2,9 & 0,0 & 67,4 & 11,8 \\
\hline $\begin{array}{l}\text { Частка довгострокових фрінансових } \\
\text { інвестицій в активах }\end{array}$ & 0,8 & 0,0 & 0,0 & 14,1 & 2,9 \\
\hline Частка основних засобів в активах & 47,5 & 47,0 & 2,6 & 95,5 & 23,3 \\
\hline
\end{tabular}


ротних активів. Важливим у даному процесі $€$ контроль за дотриманням нормативного значення показника забезпечення власними оборотними засобами запасів та перевищення коесріцієнта покриття запасів одиниці.

Такі зміни також можуть сприяти певним позитивним змінам щодо періоду одного обороту запасів і тривалості виробничого циклу, а на решту показників фрінансового стану підприємства буде здійснено несуттєвий вплив. У другій групі показників найбільше взаємозв'язків має коефріцієнт маневреності власного капіталу.

Так, зменшення обсягу необоротних активів та збільшення обсягу довгострокового фрінансування дозволить збільшити фрінансову стійкість, фрінансову автономію, стійкість економічного зростання, забезпеченість власними оборотними засобами та рентабельність власного капіталу.

Відтак, зазначені аграрні підприємства протягом досліджуваного періоду мали гірший фрінансовий стан у порівнянні із галузевим рівнем, що спричинено негативною динамікою фрормування прибутку від операційної діяльності та чистого прибутку. Запропоновано забезпечити збалансування показників срінансового стану аграрних підприємств на основі здійснення впливу на ключові точки

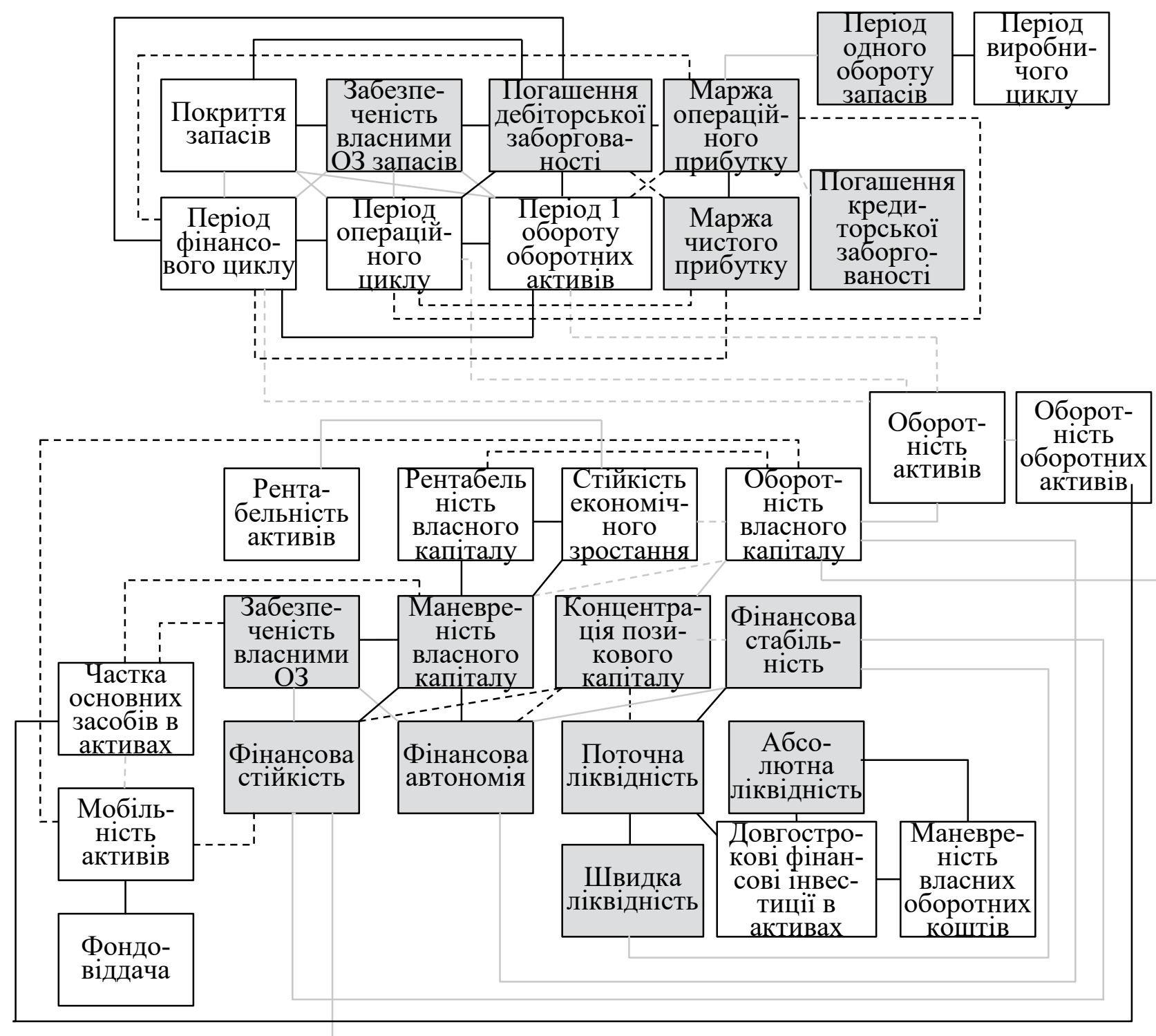

Рис. 1. Схема взаємозв'язків між показниками фрінансового стану аграрних підприємств Одеської області

*безперервна лінія вказує на позитивну кореляцію, пунктирна лінія - на від'ємну кореляцію; чорним кольором позначена висока кореляція (0,67 і більше), а сірим - від 0,5 до 0,67 
впливу, зміна яких сприятиме оптимізації решти показників на основі синергічного еоректу. Встановлено, що такими точками $є$ період погашення дебіторської заборгованості та коефіцієнт маневреності власного капіталу.

Розраховані показники фрінансового стану аграрних підприємств України являються основою для визначення показника ефрективності управління розвитком фінансової діяльності зазначених підприємств, що є різницею «між одиницею та середнім арифрметичним відношень абсолютних відхилень від норми показників фрінансового стану у поточному році до максимальних відхилень протягом досліджуваного періоду» [23]. У результаті обчислень отримано коефіцієнти ефективності для п‘ятнадцяти підприємств Одеської області (рис. 2).

Відтак, середній рівень ефрективності управління розвитком фрінансової діяльності п'ятнадцяти аграрних підприємств Одеської області зменшився на 10,3\% за шість років. При цьому серед досліджуваних підприємств прослідковуються три тенденції:

1) тенденція до зростання рівня коефіцієнта: ДП ДГ «Реконструкція» (на 17,5\% у 2020 р. у порівнянні 32015 р.), ДП ДГ «Зелені Кошари» (на 15,6\% у 2020 р. у порівнянні 3 2015 р.), ПрАТ «Перемога» (на 12,8\% у 2020 р. у порівнянні 32015 р.) та ПрАТ «Долинка» (на $16,9 \%$ у 2020 р. у порівнянні з 2015 р.);

2) тенденція до незначного зниження ефективності управління розвитком фрінансової діяльності (до 20\%): ДП ДГ «Комунар» (на 1,3\% у 2020 р. у порівнянні 32015 р.), ДП ДГ «Мирнопільське» (на 10,1\% у 2020 р. у порівнянні 32015 р.), ДП ДГ «Жеребківське» (на 12,2\% у 2020 р. у порівнянні 32015 р.), ДП ДГ «Покровське» (на 10,6\% у 2020 р. у порівнянні 32015 р.), ДП ДГ «Дачна» (на 19,3\% у 2020 р. у порівнянні 32015 р.), ПрАТ «Дружба» (на 14,8\% у 2020 р. у порівнянні 32015 р.) та ПАТ «Сонячне» (на 7,9\% у 2020 р. у порівнянні з 2015 р.);

3) тенденція до значного зниження ефективності управління розвитком фрінансової діяльності (більше 20\%): ПрАТ «Старосілля» (на 44,1\% у 2020 р. у порівнянні 32015 р.), ПрАТ «Ізмаїл-Наваско» (на 47,1\% у 2020 р. у порівнянні 32015 р.), ДП ДГ «Южний» (на $25,4 \%$ у 2020 р. у порівнянні 32015 р.) та ПАТ «Мирний» (на 24,6\% у 2020 р. у порівнянні 32015 р.).

Так як на рівні підприємства змінам піддаються лише фрактори внутрішнього середовища, проведемо регресійний аналіз ефективності управління розвитком фрінансової діяльності на основі таких факторів:

- кадрове забезпечення - середньорічна кількість працівників;

- рівень спеціалізації - одиниця поділена на кількість видів економічної діяльності за кожним досліджуваним аграрним підприємСтВОМ;

- доступність джерел фрінансування - кількість доступних джерел фрінансування за кожним досліджуваним аграрним підприємством;

- темп зростання розміру підприємства темп зростання балансової вартості активів;

- земля - урожайність сільськогосподарських культур.

Описова статистика для регресійної моделі наведена в таблиці 3.

Описова статистика для регресійної моделі, 2015-2020 рр.

Таблиця 3

\begin{tabular}{|l|c|c|c|c|c|c|}
\hline \multicolumn{1}{|c|}{ Показники } & $\begin{array}{c}\text { Умовні } \\
\text { позначення }\end{array}$ & $\begin{array}{c}\text { Середнє } \\
\text { значення }\end{array}$ & Медіана & Мінімум & Максимум & $\begin{array}{c}\text { Кількість } \\
\text { спостережень }\end{array}$ \\
\hline Ефективність, \% & $\mathrm{E}$ & 65,50 & 69,35 & 24,86 & 85,33 & 90 \\
\hline $\begin{array}{l}\text { Кількість працівників, } \\
\text { осіб }\end{array}$ & $\mathrm{SP}$ & 49 & 45 & 4 & 125 & 90 \\
\hline Рівень спеціалізації, \% & $\mathrm{SL}$ & 12,74 & 11,11 & 3,85 & 25,00 & 90 \\
\hline $\begin{array}{l}\text { Кількість джерел } \\
\text { фрінансування }\end{array}$ & $\mathrm{F}$ & 4 & 4 & 2 & 6 & 90 \\
\hline $\begin{array}{l}\text { Темп зростання } \\
\text { балансової вартості } \\
\text { активів, \% }\end{array}$ & $\mathrm{B}$ & 111,30 & 105,83 & 57,29 & 197,07 & 90 \\
\hline $\begin{array}{l}\text { Урожайність } \\
\text { сільськогосподарських } \\
\text { культур з розрахунку } \\
\text { на 1 га, ц }\end{array}$ & $\mathrm{H}$ & 30,24 & 32,04 & 4,32 & 68,00 & 90 \\
\hline
\end{tabular}




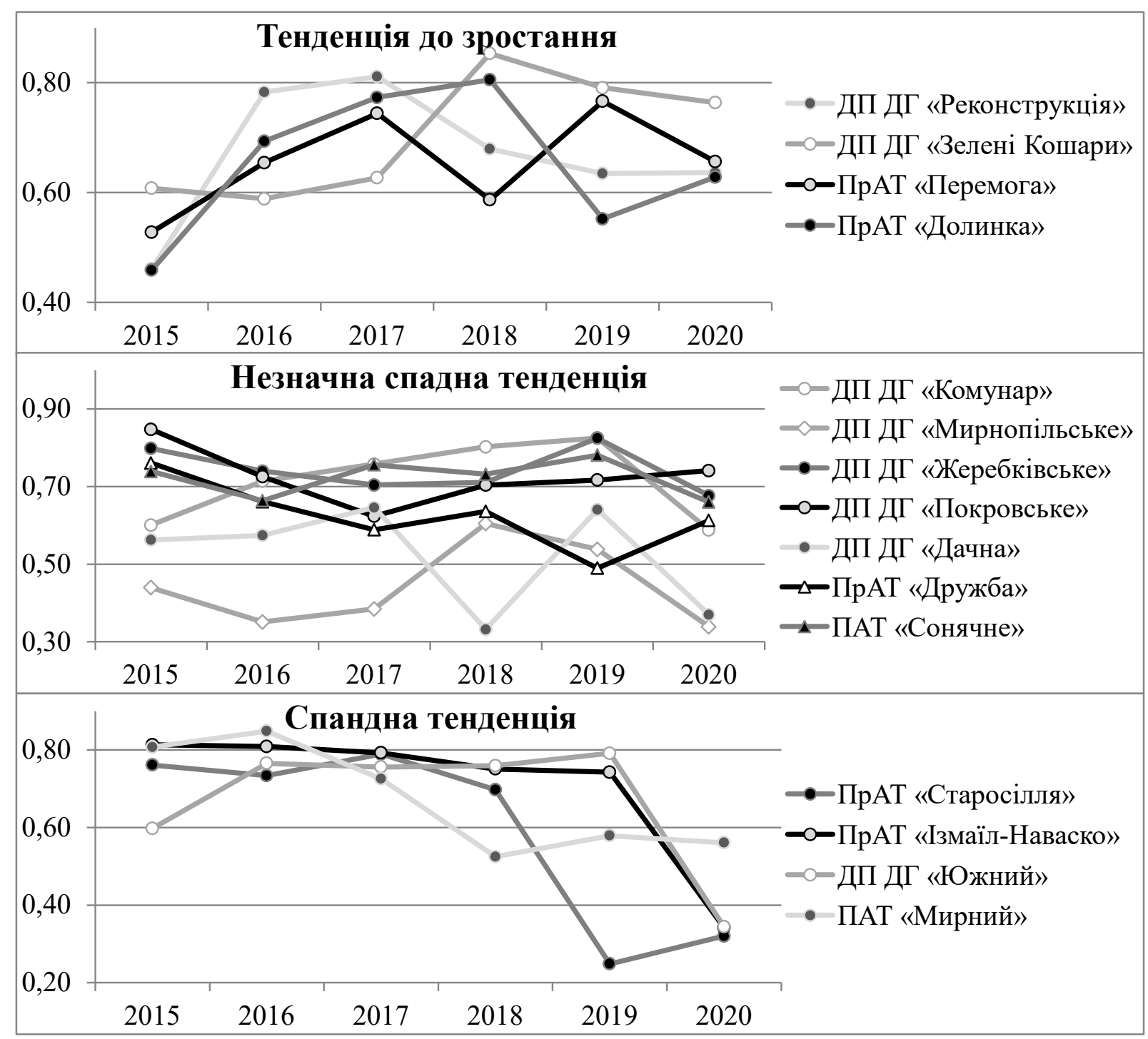

Рис. 2. Коефріцієнти ефективності управління розвитком фрінансової діяльності аграрних підприємств, 2015-2020 рр.

Джерело: обчислено на основі даних з [22]

У результаті регресійного аналізу отримано наступну фрункціональну залежність (1). $E=28,39+0,15 \cdot S P+0,62 \cdot S L+0,54 \cdot F+0,13 \cdot B+0,16 \cdot H ;$; (1)

Дана рівність дозволяє стверджувати наступне:

1. Ефрективність розвитку фрінансової діяльності аграрних підприємств України залежить від кількості працівників, рівня спеціалізації, кількості джерел фрінансування, темпу зростання балансової вартості активів та урожайності сільськогосподарських культур. Зазначені фрактори на 46,2\% впливають на ефрективність управління розвитком фрінансової діяльності аграрних підприємств України, адже коефріцієнт $R^{2}=0,462$. Решта впливу припадає на фрактори місцевого, національного та міжнародного середовища.
2. Між кількістю штатних працівників аграрних підприємств та ефрективністю управління розвитком фрінансової діяльності існує прямопропорційна залежність, тобто при збільшенні кількості працівників на 10 осіб коефріцієнт есрективності зростає на 1,5 відсоткових пунктів.

3. Кожен додатковий вид економічної діяльності ускладнює процес управління розвитком фрінансової діяльності аграрного підприємства. Збільшення рівня спеціалізації на $10 \%$ дозволяє підвищити рівень коесріцієнта ефрективності управління розвитком фрінансової діяльності аграрного підприємства на 6,2\%. Серед досліджуваних підприємств найбільша кількість видів діяльності здійснювало ДП ДГ «Южний» (26). При зменшенні кіль- 
кості видів діяльності до 25-ти рівень спеціалізації збільшиться на 0,2\%, а коефріцієнт на 0,1\%, а при зменшенні до 20-ти рівень спеціалізації становитиме $5 \%$, а коефіцієнт зросте на 0,7\%. За умови зменшення кількості видів діяльності ДП ДГ «Зелені Кошари» 3 20-ти до 19-ти едрективність управління збільшиться на 0,2\%, а при зменшенні до 16-ти - на 0,8\%. Зменшення кількості видів діяльності ДП ДГ «Жеребківське» 3 16-ти до 15-ти дозволить підвищити ефективність управління розвитком фрінансової діяльності підприємства на 0,3\%. Скорочення видів діяльності ДП ДГ «Реконструкція» 3 14-ти до 13-ти сприятиме збільшенню рівня коефріцієнта на 0,3\%. Підвищення рівня спеціалізації ДП ДГ «Мирнопільське», ДП ДГ «Покровське» та ДП ДГ «Дачна» до 9,1\% (3 12-ти до 11-ти КВЕД) дозволить збільшити зазначений коефріцієнт на 0,5\%. Зменшення кількості видів діяльності ПрАТ «Перемога» та ПрАТ «Старосілля» 3 9-ти до 8-ми збільшить рівень коефріцієнта на 0,9 відсоткових пунктів. Збільшення рівня спеціалізації ПрАТ «Дружба» 3 16,7\% до $20 \%$ дозволить підвищити ефективність управління розвитком фрінансової діяльності на 2,1\%. При зменшенні кількості видів діяльності ПрАТ «Долинка», ПрАТ «ІзмаїлНаваско» та ПАТ «Сонячне», ДП ДГ «Комунар» 3 5-ти до 4-х коефріцієнт зросте на 3,1 відсоткових пунктів, а при зменшенні кількості видів діяльності ПАТ «Мирний» з 4-х до трьох коефріцієнт ефективності зросте на 5,2 відсоткових пунктів.

Дана тенденція пояснюється тим, що кожна додаткова економічна діяльність ускладнює систему взаємозв'язків між внутрішніми процесами підприємства, тобто забезпечення оптимального розвитку потребує більше часу на виявлення закономірностей перебігу процесів та підбір оптимальних управлінських рішень.

4. Кожне додаткове джерело фрінансування збільшує показник ефективності управління розвитком фрінансової діяльності аграрного підприємства на 0,5\%. Це пояснюється тим, що диверсифрікованість зовнішнього фрінансування дозволяє зменшити ризики залучення капіталу, а також обирати найбільш економічно вигідні фрінансові інструменти.

5. Темп зростання балансової вартості активів здійснює прямопропорційний вплив на ефрективність управління розвитком фрінансової діяльності аграрних підприємств. Отже, при зростанні балансової вартості активів на
10\% коефріцієнт збільшиться на 1,3 відсоткових пунктів.

5. Між урожайністю сільськогосподарських культур та ефективністю управління розвитком фрінансової діяльності аграрного підприємства існує прямопропорційна залежність. Рівність (1) вказує на те, що збільшення урожайності на 1 ц з розрахунку на 1га дозволяє збільшити коефріцієнт ефрективності на 0,16 відсоткових пунктів.

Висновки. У результаті проведеного дослідження встановлено, що попри достатність власних оборотних засобів для забезпечення виробничо-збутового процесу в умовах обмеженості позикових коштів, достатність власного капіталу для орінансування активів, достатність оборотних активів для своєчасного розрахунку за зобов'язаннями, вчасне погашення дебіторської заборгованості клієнтами, а також наявність фрінансової автономії, стабільності та стійкості, аграрні підприємства Одеської області неефективно управляють запасами та кредиторською заборгованістю, а також мають недостатній рівень маржі чистого прибутку та маржі операційного прибутку. Компаративний аналіз показників без нормативного значення дозволив встановити, що досліджувані аграрні підприємства мали гірший фрінансовий стан у порівнянні зі станом по Україні. На основі кореляційного аналізу сорормовано схему взаємозв'язків між показниками орінансового стану аграрних підприємств, що дозволила виявити точки впливу, оптимізація яких завдяки синергічному ефректу дозволяє нормалізувати решту показників. Визначено, що такими точками $€$ період погашення дебіторської заборгованості та коефіцієнт маневреності власного капіталу.

Результати оцінки ефективності управління розвитком фрінансової діяльності аграрних підприємств Одеської області дозволив виявити тенденцію до зростання коефріцієнтів у чотирьох аграрних підприємствах, тенденцію до незначного зменшення у семи аграрних підприємствах та тенденцію до значного зменшення у решти досліджуваних підприємств. За допомогою регресійного аналізу доведено, що на рівень ефективності управління розвитком фрінансової діяльності аграрних підприємств позитивно впливають кількість працівників, рівень спеціалізації, кількість джерел фрінансування, темп зростання балансової вартості активів та урожайність сільськогосподарських культур. 


\section{СПИСОК ВИКОРИСТАНИХ ДЖЕРЕЛ:}

1. Suciu Gheorghe, Bârsan Pipu-Nicolae Financial diagnosis of a company's activities. Annals of the „Constantin Brâncuşi" University of Târgu Jiu, Economy Series, Issue 6/2013. URL: https://core.ac.uk/download/pdf/27252668.pdf (дата звернення: 09.08.2021).

2. Suciu Gheorghe Diagnosis of financial equilibrium. Annals of the "Constantin Brâncuşi” University of Târgu Jiu, Economy Series, Issue 2/2013. C. 273-276. URL: http://docplayer.net/10950215-Diagnosis-of-financial-equilibrium.html

3. Копчак Ю.С. Проблеми діагностики фрінансового стану і стійкості фрункціонування підприємства. Вісник СумДУ. 2016. № 9(68). С. 23-34.

4. Лук'янова В.В., Лабунець О.О. Діагностика фрінансового стану підприємства та шляхи його поліпшення. Економіка та управління підприємствами. 2018. Випуск 2(07). С. 66-69.

5. Мищишин О.Л., Федорович І.С. Діагностика фрінансового стану як інструмент ефрективного управління розвитком підприємства. Проблеми формування та розвитку інноваційної інфрраструктури. С. 654-655. Lviv Polytechnic National University Institutional Repository. URL: http://ena.lp.edu. иа (дата звернення: 25.05.2021).

6. Горбунова А.В. Удосконалення механізму діагностики фінансового стану підприємства. Вісник Запорізького національного університету. Економічні науки. 2014. № 2. С. 15-28.

7. Підхомний О.М. Діагностика фрінансового стану підприємства. Економічні науки. Серія «Облік і фрінанси». 2017. Вип. 23. С. 234-237.

8. Маринич І.А., Дзіковський І.І. Сучасні підходи до діагностики фінансового потенціалу підприємства. Науковий вісник НЛтУ України. 2010. Вип. 20.1. С. 105-108.

9. Левченко Н.М. Фінансовий потенціал підприємства: сутність та підходи до діагностики. Інвестиції: практика та досвід. 2012. № 2. С. 114-117. URL: http://www.investplan.com.ua/pdf/2_2012/32.pdf (дата звернення: 25.05.2021)

10. Марченко В.В. Моніторинг і діагностика рівня забезпечення стратегічного управління інноваційним розвитком підприємства. Причорноморські економічні студії. 2019. Випуск 39-1. С. 99-104.

11. Варава Л.М., Афранасьєв Є.В., Арутюнян А.Р. Комплексна інтегрована оцінка рівня ефрективності корпоративного управління на основі фрінансово-економічних показників підприємства. Актуальні проблеми сучасного менеджменту : колективна монографрія / за заг. ред. д-ра екон. наук, проф. Л.М. Варави. Кривий Ріг : Вид. Р.А. Козлов, 2018. 203 с.

12. Кривов'язюк І.В., Кость Я.О. Математико-статистичне моделювання у фінансовій діагностиці підприємств. Ефрективна економіка. 2010. № 5. URL: http://www.economy.nayka.com.ua/?op=1\&z=208\# (дата звернення: 30.05.2021).

13. Найда А.В., Тоткало І.А. Напрями підвищення економічної ефрективності господарської діяльності аграрних підприємств. Аграрній вісник Причорномор'я, серія «Економічні науки». 2018. Випуск 89. С. 83-91.

14. Бахчиванжи Л.А., Пучко Н.С. Шляхи удосконалення методики аналізу і аудиту дебіторської заборгованості в аграрних акціонерних товариствах: економетричний аспект. Аграрний вісник Причорномор'я». Серія «Економічні науки». 2018. Випуск 89. С. 143-152.

15. Пармаклі Д., Деркач Т., Бахчиванжи Л. Методика розрахунків прямого і супутнього ефректу зростання обсягів реалізації продукції в агропромислових підприємствах. Світ фрінансів. 2019. № 3(60). С. 87-98.

16. Пармаклі Д.М., Деркач Т.В., Бахчиванжи Л.А. Методичний інструментарій прогнозування прибутку у бізнес-плануванні підприємницької діяльності підприємств аграрного сектора. Вісник ОНУ імені І.І. Мечникова. 2020. Т. 25. Випуск 6(85). С. 158-166.

17. Бахчиванжи Л.А., Кіщенко А.М. Обґрунтування стратегії відтворення основних засобів аграрних підприємств. Аграрний вісник Причорномор'я. Одеса, 2017. Вип. 86. С. 18-33.

18. Бахчиванжи Л.А., Златов М.М. Діагностика стану обліково-аналітичного забезпечення управління поточними біологічними активами тваринництва у сільськогосподарських кооперативах. Глобальні та національні проблеми економіки: електронне наукове фрахове видання. Випуск 15, лютий 2017 р. URL: http://global-national.in.ua/issue-15-2017 (дата звернення: 30.05.2021).

19. Конопльова О.І. Оцінка ефрективності фрінансового забезпечення аграрних підприємств. Аграрний вісник Причорномор'я. 2011. № 60. URL: http://lib.osau.edu.ua/jspui/bitstream/123456789/294/1/Konopleva.pdf (дата звернення: 30.06.2021).

20. Морозюк Н.С., Стоянова-Коваль С.С., Губко В.І. Аналіз фінансових результатів СВК «Дружба» в розрізі сільськогосподарських підприємств Саратського району Одеської області. Вісник Одеського національного університету. 2015. № 6. С. 252-258.

21. Лівінський А.І. Оцінка діяльності м'ясопереробних підприємств за показниками їх фрінансового стану. Вісник Сумського національного аграрного університету. Серія «Економіка і менеджмент». 2017. Випуск 12(17). С. 87-90. 
22. Агентство 3 розвитку інсраструктури фрондового ринку України. Бази даних. Емітенти. URL: https://smida.gov.ua/ (дата звернення: 12.07.2021).

23. Барбінягра О.М. Оцінка ефективності управління розвитком фрінансової діяльності аграрних підприємств. The Scientific Heritage. 2021. № 69(1). C. 6-11.

\section{REFERENCES:}

1. Gheorghe S., Pipu-Nicolae B. (2013) Financial diagnosis of a companys activities. Annals of the „Constantin Brâncuşi" University of Târgu Jiu, Economy Series, no.6. Available at: https://core.ac.uk/download/pdf/27252668.pdf (accessed 9 August 2021).

2. Gheorghe S. (2013) Diagnosis of financial equilibrium. Annals of the „Constantin Brâncuşi” University of Târgu Jiu, Economy Series, no. 2, pp. 273-276. Available at: http://docplayer.net/10950215-Diagnosis-of-financial-equilibrium.html

3. Kopchak Yu.S. (2016) Problemy diahnostyky finansovoho stanu i stiikosti funktsionuvannia pidpryiemstva [Problems of diagnostics of a financial condition and stability of functioning of the enterprise]. Visnyk SumDU, no. 9(68), pp. 23-34.

4. Lukianova V.V., Labunets O.O. (2018) Diahnostyka finansovoho stanu pidpryiemstva ta shliakhy yoho polipshennia [Diagnosis of the financial condition of the enterprise and ways to improve it]. Ekonomika ta upravlinnia pidpryiemstvamy, vol. 2(07), pp. 66-69.

5. Myshchyshyn O.L., Fedorovych I.S. (2015) Diahnostyka finansovoho stanu yak instrument efektyvnoho upravlinnia rozvytkom pidpryiemstva [Diagnosis of financial condition as a tool for effective management of enterprise development]. Problemy formuvannia ta rozvytku innovatsiinoi infrastruktury, pp. 654-655. Available at: http://ena.Ip.edu.ua (accessed 25 May 2021).

6. Horbunova A. V. (2014) Udoskonalennia mekhanizmu diahnostyky finansovoho stanu pidpryiemstva [Improving the mechanism for diagnosing the financial condition of the enterprise]. Visnyk Zaporizkoho natsionalnoho universytetu. Ekonomichni nauky, no. 2, pp. 15-28.

7. Pidkhomnyi O.M. (2017) Diahnostyka finansovoho stanu pidpryiemstva [Diagnosis of the financial condition of the enterprise]. Ekonomichni nauky. Seriia «Oblik i finansy», vol. 23, pp. 234-237.

8. Marynych I.A., Dzikovskyi I.I. (2010) Suchasni pidkhody do diahnostyky finansovoho potentsialu pidpryiemstva [Modern approaches to the diagnosis of the financial potential of the enterprise]. Naukovyi visnyk NLTU Ukrainy, vol. 20.1, pp. 105-108.

9. Levchenko N.M. (2012) Finansovyi potentsial pidpryiemstva: sutnist ta pidkhody do diahnostyky [The financial potential of the enterprise: the essence and approaches to diagnosis]. Investytsii: praktyka ta dosvid, no. 2, pp. 114-117. Available at: http://www.investplan.com.ua/pdf/2_2012/32.pdf (accessed 25 May 2021).

10. Marchenko V.V. (2019) Monitorynh i diahnostyka rivnia zabezpechennia stratehichnoho upravlinnia innovatsiinym rozvytkom pidpryiemstva [Monitoring and diagnostics of the level of providing strategic management of innovative development of the enterprise]. Prychornomorski ekonomichni studii, vol. 39-1, pp. 99-104.

11.Varava L.M., Afanasiev Ye.V., Arutiunian A.R. (2018) Kompleksna intehrovana otsinka rivnia efektyvnosti korporatyvnoho upravlinnia na osnovi finansovo-ekonomichnykh pokaznykiv pidpryiemstva [Comprehensive integrated assessment of the level of efficiency of corporate governance based on financial and economic indicators of the enterprise]. Aktualni problemy suchasnoho menedzhmentu: kolektyvna monohrafiia / za zah. red. d-ra ekon. nauk, prof. L.M. Varavy. Kryvyi Rih: Vyd. R.A. Kozlov, 203 p. (in Ukrainian)

12. Kryvoviaziuk I.V., Kost Ya.O. (2010) Matematyko-statystychne modeliuvannia u finansovii diahnostytsi pidpryiemstv [Mathematical and statistical modeling in financial diagnostics of enterprises]. Efektyvna ekonomika, no. 5. Available at: http://www.economy.nayka.com.ua/?op=1\&z=208\# (accessed 30 May 2021).

13. Naida A.V., Totkalo I.A. (2018) Napriamy pidvyshchennia ekonomichnoi efektyvnosti hospodarskoi diialnosti ahrarnykh pidpryiemstv [Directions for increasing the economic efficiency of economic activity of agricultural enterprises]. Ahrarnii visnyk Prychornomoria. Seriia «Ekonomichni nauky», vol. 89, pp. 83-91.

14. Bakhchyvanzhy L.A., Puchko N.S. (2018) Shliakhy udoskonalennia metodyky analizu i audytu debitorskoi zaborhovanosti $v$ ahrarnykh aktsionernykh tovarystvakh: ekonometrychnyi aspect [Ways to improve the methodology of analysis and audit of receivables in agricultural joint stock companies: econometric aspect]. Ahrarnyi visnyk Prychornomoria. Seriia «Ekonomichni nauky», vol. 89, pp. 143-152.

15. Parmakli D., Derkach T., Bakhchyvanzhy L. (2019) Metodyka rozrakhunkiv priamoho i suputnoho efektu zrostannia obsiahiv realizatsii produktsii $v$ ahropromyslovykh pidpryiemstvakh [Methods of calculating the direct and concomitant effect of growth in sales in agro-industrial enterprises]. Svit finansiv, no. 3(60), pp. 87-98.

16. Parmakli D.M., Derkach T.V., Bakhchyvanzhy L.A. (2020) Metodychnyi instrumentarii prohnozuvannia prybutku u biznes-planuvanni pidpryiemnytskoi diialnosti pidpryiemstv ahrarnoho sektora [Methodical tools for profit 
forecasting in business planning of entrepreneurial activity of enterprises of the agricultural sector]. Visnyk ONU imeni I.I. Mechnykova, vol. 25, no. 6(85), pp. 158-166.

17. Bakhchyvanzhy L.A., Kishchenko A.M. (2017) Obgruntuvannia stratehii vidtvorennia osnovnykh zasobiv ahrarnykh pidpryiemstv [Substantiation of the strategy of reproduction of fixed assets of agricultural enterprises]. Ahrarnyi visnyk Prychornomoria, vol. 86, pp. 18-33.

18. Bakhchyvanzhy L.A., Zlatov M.M. (2017) Diahnostyka stanu oblikovo-analitychnoho zabezpechennia upravlinnia potochnymy biolohichnymy aktyvamy tvarynnytstva u silskohospodarskykh kooperatyvakh [Diagnosis of the state of accounting and analytical support for the management of current biological assets of livestock in agricultural cooperatives]. Hlobalni ta natsionalni problemy ekonomiky, no. 15, liutyi 2017 r. Available at: http://global-national.in.ua/issue-15-2017 (accessed 30 May 2021).

19. Konoplova O.I. (2011) Otsinka efektyvnosti finansovoho zabezpechennia ahrarnykh pidpryiemstv [Evaluation of the effectiveness of financial support of agricultural enterprises]. Ahrarnyi visnyk Prychornomoria, no. 60. Available at: http://lib.osau.edu.ua/jspui/bitstream/123456789/294/1/Konopleva.pdf (accessed 30 June 2021).

20. Moroziuk N.S., Stoianova-Koval S.S., Hubko V.I. (2015) Analiz finansovykh rezultativ SVK «Druzhba» v rozrizi silskohospodarskykh pidpryiemstv Saratskoho raionu Odeskoi oblasti [Analysis of financial results of Druzhba Agricultural Complex in terms of agricultural enterprises of Saratsky district of Odessa region]. Visnyk Odeskoho natsionalnoho universytetu, no. 6, pp. 252-258.

21. Livinskyi A.I. (2017) Otsinka diialnosti miasopererobnykh pidpryiemstv za pokaznykamy yikh finansovoho stanu [Evaluation of meat processing enterprises according to their financial condition]. Visnyk Cumskoho natsionalnoho ahrarnoho universytetu. Seriia «Ekonomika i menedzhment», no. 12(17), pp. 87-90.

22. Stock Market Infrastructure Development Agency of Ukraine. Database. Emitenty [Issuers]. Available at: https://smida.gov.ua/ (accessed 12 July 2021).

23. Barbiniahra O.M. (2021) Otsinka efektyvnosti upravlinnia rozvytkom finansovoi diialnosti ahrarnykh pidpryiemstv [Effectiveness evaluation for the financial activities development management of agricultural enterprises]. The Scientific Heritage, no. 69(1), pp. 6-11. 